\title{
Health care accessibility and disparities in medical staff availability in Latvia
}

\author{
Ieva Bikava $^{1}$ and Andris Skride ${ }^{2}$ \\ ${ }^{1}$ Rīga Stradiņš University, Riga, Latvia \\ ${ }^{2}$ Rīga Stradinsš University, Department of Internal Diseases, Riga, Latvia
}

\begin{abstract}
The Health care accessibility for inhabitants, especially in rural regions, is related to the problem of the medical staff availability in state and municipal hospitals and ambulatory institutions as well as for General Practitioners.

Despite the fact, that there are two state Universities - University of Latvia and Rīga Stradiņš University, as well as colleges, that educate medical staff - there is a lack of human resources in health care institutions in Latvia.

The Ministry of Health and municipalities had several initiatives to solve this problem - changes in regulations for Residency students, programme financed by European Funds with obtainable funding in the amount of 10 million euro, as well as different stimuli and programmes from municipalities.

The research explores the current situation with staff availability and, basing on interviews and outcomes, analyzes the effectiveness of the available programmes to attract human resources, and predict the impact and outcomes of those activities.

The results showed that all the programmes had some fragmented positive impact and partially solve the problem, but those activities will not provide sufficient outcomes and the problem of medical staff availability will still be the urgent topic in future.
\end{abstract}

Key words: health policy, regional disparities, medical specialist availability, human resources in health care.

\section{Introduction}

The slogan - to provide qualitative, affordable and accessible to inhabitants health care services - has been used for implementation of different reforms since the 1991. Countless changes have been planned and implemented in health care sector under this flag, but the problem with availability of health care service persists.

One of the indicators describing the results of achieved availability is the data on unmet needs of inhabitants (Table 1).

Analysis of reasons for unmet needs indicates that the leading obstacle is high costs for both urban and rural inhabitants. In the course of time, the main cause - "too expensive" - is decreasing, but other warning trend is arising - the share of people who postpone the medical care rises significantly, which can also be explained with financial issues.

"Too far to travel" is not one of the leading obstacles, but at the same time is twice higher for rural than urban population. All indicators show that the level of unmet needs is higher for rural than the urban population.

The deeper analysis of inhabitant behaviour showed, that there is another tendency in Latvia related to healthcare availability - the high rate of out-of-pocket payments for those, 
Table 1. Reasons for unmet needs for medical care for persons 16 or over (\%) [1].

\begin{tabular}{|l|c|c|c|c|c|c|}
\hline Reason & \multicolumn{2}{|c|}{$\begin{array}{c}\text { Could not afford to } \\
\text { too expensive) }\end{array}$} & \multicolumn{2}{c|}{$\begin{array}{c}\text { Wanted to wait and } \\
\text { see if problem got } \\
\text { better on its own }\end{array}$} & \multicolumn{2}{c|}{$\begin{array}{c}\text { Too far to travel/ } \\
\text { no means of } \\
\text { transportation }\end{array}$} \\
\hline Year & Urban & Rural & Urban & Rural & Urban & Rural \\
\hline 2013 & 60.9 & 58.1 & 13.7 & 21.5 & 1.8 & 4.4 \\
\hline 2014 & 53.7 & 56.1 & 15.1 & 27.1 & 1.7 & 3.6 \\
\hline 2015 & 57.2 & 59.1 & 14.5 & 18.4 & 2.2 & 4.2 \\
\hline 2016 & 41.7 & 51.2 & 16.4 & 20.9 & 2.9 & 6.1 \\
\hline 2017 & 42.5 & 44.6 & 21.6 & 25.4 & 3.3 & 6.6 \\
\hline
\end{tabular}

Table 2. Health Spending. Out of Pocket in percentage of health spending [2].

\begin{tabular}{|l|c|c|c|c|c|c|c|c|}
\hline Year, \% & $\mathbf{2 0 0 9}$ & $\mathbf{2 0 1 0}$ & $\mathbf{2 0 1 1}$ & $\mathbf{2 0 1 2}$ & $\mathbf{2 0 1 3}$ & $\mathbf{2 0 1 4}$ & $\mathbf{2 0 1 5}$ & $\mathbf{2 0 1 6}$ \\
\hline Estonia & 20.34 & 21.92 & 21.56 & 21.52 & 22.61 & 22.62 & 22.77 & 22.69 \\
\hline Latvia & 38.78 & 37.19 & 34.3 & 37.82 & 38.47 & 39.11 & 42.07 & 44.56 \\
\hline Lithuania & 26.82 & 27.59 & 28.22 & 31.80 & 32.82 & 31.49 & 31.84 & 32.34 \\
\hline
\end{tabular}

who got the medical service they needed. The level of out-of-pocket payment in Latvia reached more than $40 \%$ rate and in comparison to both neighbour states is highest not only among Baltic States, but also is the highest in European Union (Table 2).

High rate of out-of-pocket payments are not associated with more expensive service price in Latvia, in comparison with other Baltic states, but is due to the shortage of state provided service volume. The deficit of state provided service push an inhabitant to choose receiving of the service in private sector paying the full price.

There are several services and specialists, but to receive the service there is a queue for several months to wait. At the same time, the service or specialist appointment can be received faster, if patients are ready to pay themselves.

The long waiting lists are related to the amount of funding that state can pay to service provider (limited amount that can be distracted to one service) as well as the capacity of service providers to supply the needed service. The limited price that state can pay to service provider known as tariff, for several services is not adequate or is insufficient, and does not cover the real expenses of the service therefore the service providers are not interested in supplying all the amount of state financed service.

In those circumstances, service suppliers overcharge the same service when it is provided to a single payer and thus, combining the amount that is paid by the state with the amount of service that is paid by a single payer, balance the profit and loss. Those improper mechanisms are the consequences of state settled under-priced tariffs [3].

When the same service is provided for a single payer for overcharged price and the undercharged price - when paid by the state, it leads to the situation that medical staff prefers to provide the service to single payers more than state paid services, because higher revenue can be earned.

Even in cases, when the tariffs are adequate or when the service provider can find the mechanisms how to motivate specialists to provide the services, there is the lack of specialists in several specialities. As acknowledged by the managers of the three Clinical Hospitals in Latvia, the lack of specialists leads to the situation when even if there is enough equipment and funding, the service cannot be provided in necessary extent due to deficiency of specialists. 
Table 3. Human resources. Medical Doctors and Nurses per 1,000 inhabitants [4, 5].

\begin{tabular}{|l|c|c|c|c|c|c|c|}
\hline Year & $\mathbf{2 0 1 0}$ & $\mathbf{2 0 1 1}$ & $\mathbf{2 0 1 2}$ & $\mathbf{2 0 1 3}$ & $\mathbf{2 0 1 4}$ & $\mathbf{2 0 1 5}$ & $\mathbf{2 0 1 6}$ \\
\hline Doctors - Estonia & 3.24 & 3.29 & 3.28 & 3.30 & 3.36 & 3.41 & 3.46 \\
\hline Doctors - Latvia & 3.11 & 3.13 & 3.14 & 3.19 & 3.22 & 3.20 & 3.21 \\
\hline Doctors - Lithuania & 3.95 & 4.10 & 4.22 & 4.28 & 4.31 & 4.34 & 4.47 \\
\hline Nurses - Estonia & 6.12 & 6.24 & 6.17 & 5.64 & 5.74 & 6.01 & 6.10 \\
\hline Nurses - Latvia & 5.01 & 4.96 & 4.86 & 4.88 & 4.82 & 4.68 & 4.64 \\
\hline Nurses - Lithuania & 7.37 & 7.54 & 7.59 & 7.55 & 7.60 & 7.66 & 7.70 \\
\hline
\end{tabular}

Table 4. Human resources. Medical and Nurse graduates per 100,000 inhabitants [6, 7].

\begin{tabular}{|l|c|c|c|c|c|c|}
\hline Year & $\mathbf{2 0 1 1}$ & $\mathbf{2 0 1 2}$ & $\mathbf{2 0 1 3}$ & $\mathbf{2 0 1 4}$ & $\mathbf{2 0 1 5}$ & $\mathbf{2 0 1 6}$ \\
\hline Medical graduates - EST & 9.42 & 10.28 & 9.71 & 10.57 & 10.11 & 11.02 \\
\hline Medical graduates - LAT & 11.26 & 11.50 & 13.46 & 14.04 & 16.18 & 16.33 \\
\hline Medical graduates - LIT & 13.44 & 13.19 & 14.81 & 14.63 & 16.39 & 16.11 \\
\hline Nursing graduates - EST & 29.15 & 34.4 & 35.43 & 34.31 & 32.61 & 32.38 \\
\hline Nursing graduates - LAT & 79.91 & 29.10 & 92.66 & 27.89 & 27.56 & 20.00 \\
\hline Nursing graduates - LIT & 18.96 & 15.86 & 16.97 & 18.28 & 18.42 & 18.96 \\
\hline
\end{tabular}

Comparing human resource data about three Baltic States (Table 3), the number of doctors per 1000 inhabitants in Latvia is increasing during the recent years, but is still lower than in other Baltic States. In comparison to the recommended level, or the average level in European Union, that is 3.5 to 1000 inhabitants, it is not critically low.

Comparison of the data about nurses shows that the number of nurses in Latvia is significantly lower than in Lithuania or Estonia. Comparing to average EU level, where the number of nurses is 8.4 per 1000 population, in Latvia the lack of nurses is significant because the rate of Latvia 4.6 is almost twice lower than average in EU 8.4.

Every year both Universities - University of Latvia and Rīga Stradiņš University, as well as other educational institutions train new specialists - new doctors, nurses and other specialists, who should replace seniors and provide service supply. According to OECD data, in comparison to Lithuania and Estonia, the level of Medical graduates in Latvia, is higher than in Estonia and quite similar with Lithuania (Table 4).

The average number of nursing graduates in Latvia for the last year does not significantly differ from the other Baltic States, but comparing data over a longer period, we see that in previous years from 2000 to 2010 the number of graduated nurses in Latvia was lower than in other states, so it leads to accumulative effects.

According to data obtained from the Association of nurses in Latvia, there is a large gap between registered and practicing nurses, which means that there are many nurses who have gained the education and practice but are not working as nurses (Fig. 1).

As was previously indicated, comparing data from OECD the rate of nurses per 1,000 inhabitants in Latvia and the European Union, the rate was 4.6 in Latvia to 8.4 in EU. As can be seen from the data from Association of Nurses in Latvia, if all registered nurses worked in the health care service, it would be possible to reach the average EU rate. However, the challenge is how to motivate those nurses working in other sectors to come into healthcare sector.

Another problem observed from the data of Association of nurses in Latvia is the aging problem in Nurses sector (Fig. 2).

It means that new nurses are not motivated to join medical institutions to work as nurses, but prefer work in other sectors. 


\section{Nurses in Latvia}

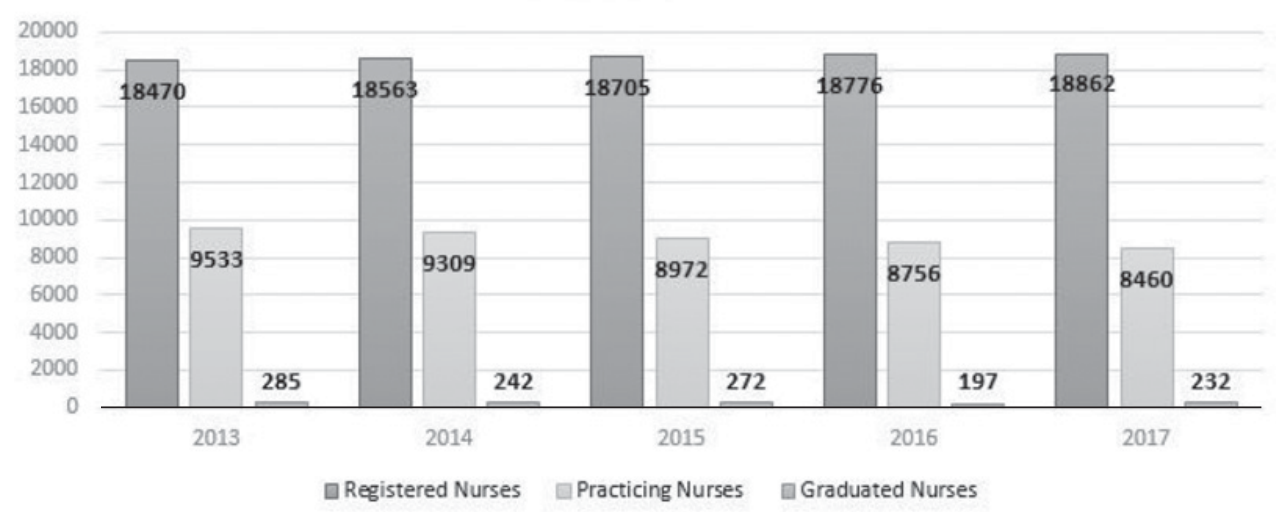

Fig. 1. Data from Medical Nurses register by year.

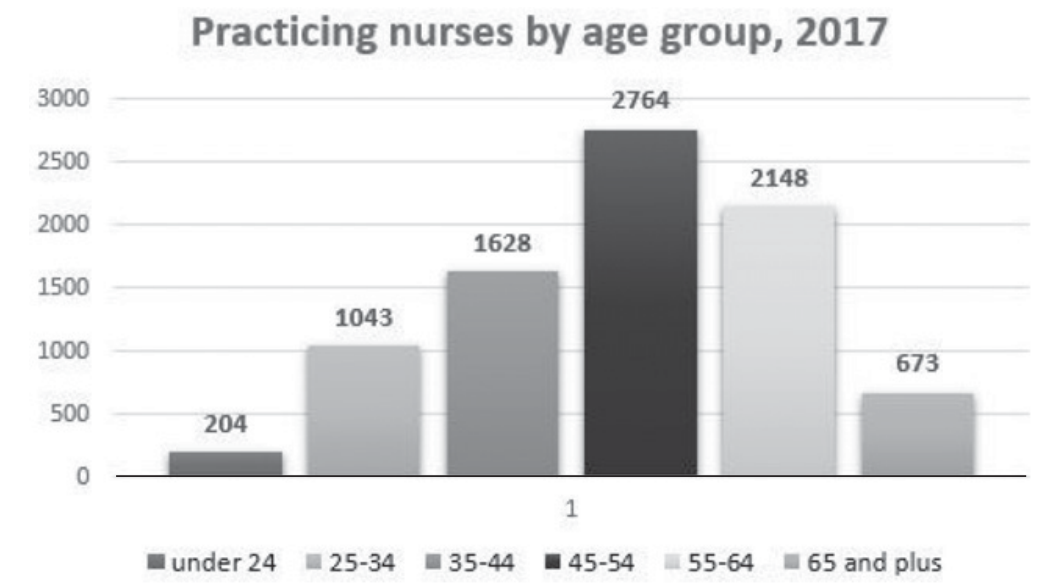

Fig. 2. Data from Medical Nurses register - Practicing nurses by age groups in 2017.

The accessibility to health care service also depends on availability of doctors. According to data on the main workplace of medical doctors - most of the doctors (62\%) work in Riga city. In Riga region and in Latgale region $-9 \%$, in Zemgale and Kurzeme - 7\% and in Vidzeme only $6 \%$ of doctors work [8]. Of course, some specialists who are working in Riga, work also as guest specialists in regions, but they cannot provide all the necessary services in regions. Due to the lack of specialists in regions, there are long waiting lists for specialist consultations and services.

The problem with the availability of specialists is not only in hospital sector, but also in primary health care. In some regions, there are not General Practitioners (GP) available due to aging problem of GPs. For example, in Staicele district in Aloja municipality where, according to data from person registry 933 persons live in Staicele city and 565 in Staicele parish from $1^{\text {st }}$ January 2019, the only GP practice has been closed because the doctor has retired and there is no new GP to replace the retired one. As the result, 899 registered patients, including 120 children are left without GP. The situation in Staicele is not unique, according to data from Rural GP association, of 1300 GP practicing in rural areas, about one third are 


\section{Practicing GP by age group, \%}

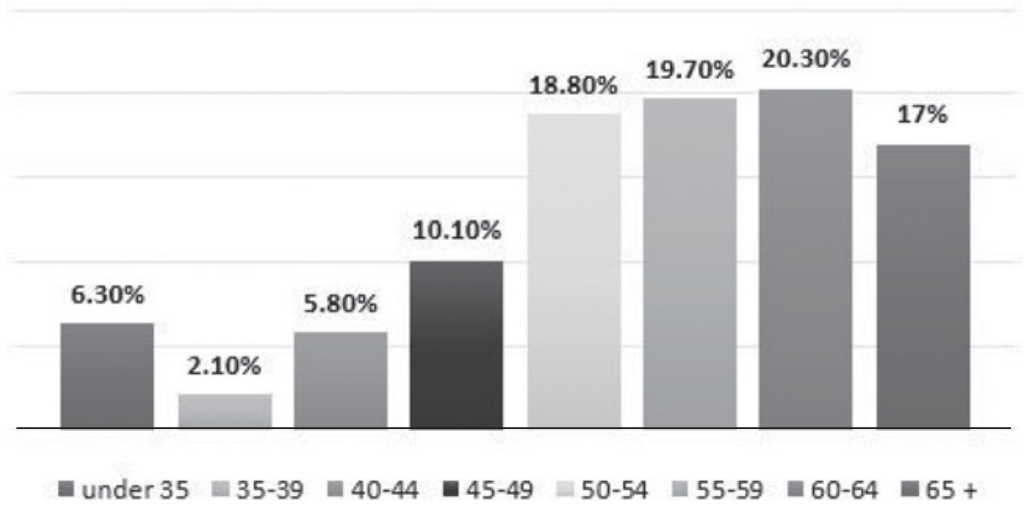

Fig. 3. Practicing GP by age group in 2017 [11].

at retirement age. In 2018, there were $380 \mathrm{GP}$, who had reached the retirement age 63, and some practicing GP were even 70 years old and older $[9,10]$.

According to data from The Centre for Disease Prevention and Control of Latvia, in 2017 more than $75 \%$ of all practicing GP had reached the age of 50 and more, and $17 \%$ of all practicing GP were of retirement age, more than 65 years old (Fig. 3).

Summarizing the above mentioned, there are significant problems with human resource in health care in Latvia, especially with nurses and GPs. The shortage can be observed in both sectors - rural and urban and is caused by the deficit of young nurses and GP entering the field in order to replace the persons at the retirement age.

In its turn, analysis of data on medical doctors does not indicate so pronounced lack of specialists in comparison to other countries, but shows significant regional disparities if comparing the number or practicing specialists in Riga and in regions.

Thus, there are two main problems in health care sector that should be addressed -how to attract more specialists - medical doctors to practice in regions, how to attract nurses to work in healthcare sector not in other sectors, and how to encourage young GP to take over practices of GPs of retirement age.

Evaluating health care in Latvia, the World Bank gave two recommendations for workforce deployment: 1) To develop the workforce in targeted specialities and geographical locations through education and training opportunities; 2) To develop multi - faceted strategies to attract and retain staff in rural areas involving career pathways, attractive living and working conditions, enhance remuneration, and recruitment of students from rural areas who will potentially return to their places of origin [12].

\section{Analysis of reasons of human resources deficit}

To get better understanding of the problem and find causes that provoke it, several interviews were carried out with representatives of health care sector - Minister of Health, Deputy Secretary of State on Health Policy Issues, managers of Project Management Division of Ministry of Health, Member of the Board of Rural GP association in Latvia, Member of the Board of Association of Nurses in Latvia, as well as Head of the Residency of Family Medicine of Rīga Stradiņš University. 
During the discussions with representatives of Nurse association and the representatives from Rural GP associations, as well as representatives from the Ministry of Health it was pointed out that significant part of young nurses do not work in health sector. They prefer work in such sectors as beauty care, in pre-school institutions, in private care institutions, and in other sectors, that are not even close to health care - in offices, in supermarkets and even in gas stations. A big part of nurses is also working abroad - some as medical nurses, but many of them as care providers in social institutions. The main reasons for making such choices are - inadequate salary, paid in both state owned and even in private sector, the other reason is that duties are too heavy physically and emotionally, and the third - the low prestige of the speciality.

Discussions about the problem with GPs revealed that there are several reasons that hinder new GP to enter health care sector. In the rural areas, it is not only the small number of inhabitants that leads to small capitation money, but also the incapacity to provide the needed health care services to patients, especially seniors. From the other side, the senior GPs are not motivated to give up their practice to the new GPs, because there are no reimbursement mechanisms to support the elder GPs. This set of conditions lead to the situation where the elderly GPs cannot provide qualitative services, but the new GPs cannot enter the market.

The research on deficit of medical specialists - doctors in rural areas, illuminated several problems - the first is the amount of salary of a specialist practicing in rural area. If a specialist works in the capital city Riga or other big city, there is a possibility to combine work in more than one institution - for example, part of the day the specialist works in a state clinic, and part of the time in private consultation. It is also possible to combine several duties during one working shift. This is common especially in clinical hospitals - to work as a specialist, to work with the residency students and to work in clinical research. Many leading specialists also give lectures to medical students or work as lecturers in further education, which is paid by pharmacy industry. The combination of duties working in more than one workplace is common not only among doctors, but also among nurses. All those activities that medical staff are forced to execute are the result of small salaries.

Another stimulus to work in state university clinics, not in the rural clinic, is the opportunities of professional development. Rural hospitals cannot provide so much ordinary episodes and even more - rare and interesting cases than can provide the university clinic. The carrier ladders are more attractive in big state clinic than in smaller rural clinic.

As the third reason why the young doctors prefer work in Riga clinics was mentioned the possibility to work with contemporary equipment and participate in trainings and exchange of experience with foreign specialists.

In addition to abovementioned, the representatives of municipalities that try to attract new specialists also mentioned other factors that are significant for the new specialists in making decision where to work. They are the living conditions, the work possibilities for the spouse, the opportunities for children - preschool and school activities, as well as possibilities to enjoy cultural events.

Another factor that plays bilateral role is Latvia as a member of the European Union. On the one hand, this partnership provides possibilities to get better education, to have possibilities to practice in other EU countries. On the other hand, the more developed countries provide better reward system for specialists and the free market legislature provides more attractive working and living conditions in Germany, Norway, Sweden and even Estonia than in Latvia. That leads to the fact that new doctors, as well as experienced doctors and nurses, decide to move to work in other countries after getting highly valued medical education and practice in Latvia. 


\section{Evaluation of activities in human resource development}

Several actions are taken by the state and municipalities to combat the deficit of medical staff, especially in rural areas, and to ensure better availability of service to inhabitants.

To attract young specialists to work in regions, from 2015 changes in regulation for state paid residency studies were made - giving priority to students who have accepted contract to work in regions after the residency for at least 3 years in state or municipality healthcare institutions. In the first study year 2015/2016 there were 20 percent or 43 of 230 new residency students who used this priority and signed contracts on work in regions after graduation [8].

This program is evaluated as successful and good references are available from regional healthcare institutions, especially from the larger regional clinics, Family Health Department and the Further Education Department in Riga Stradins University. Several articles are also available on the internet and in medical journals giving personal stories from young specialists who have residency practice in regional clinics and are planning to stay in regions for next decades.

Another group of actions are taken by municipalities with aim to attract both young and experienced specialists to work in their municipalities - medical specialists and GPs. The programmes that are performed by municipalities and the stimuli are broad - municipality pays residency in medicine, provides accommodation and special advantages to specialists and their families, gives discounts for municipality provided services, etc. Although these activities have some good results, unfortunately, the outcomes are not successful enough. Representatives of regional clinics mention some hindering factors in attraction of specialists to work in regions - environment or possibilities provided in social and culture sphere, difficulties for family members to find a job, insufficient facilities for children education, free time and sports activities. Another, very significant factor, mentioned by both state municipal representatives and by private sector is the carrier and professional development options. The small number of patients and lack of unusual cases do not give necessary challenge for young specialists. In addition, the new reforms with specialization of the rural clinics also have impact on long-term forecasts of further clinic development. Another obstacle is common to the whole of Health care sector - insufficient salary and the lack of human resources that make the existing staff overwork.

To solve the problem with medical staff availability in regions in 2017 the new state programme was initiated within the European Union Social Program "Investing in People" under the aim section "Growth and Employment". A specific program for specific support purpose - "SAM.9.2.5. - to improve health care accessibility in priority areas for inhabitants whose residency is outside Riga". The program provides special compensations or financial benefits to ensure activities necessary to move and start to work in other region. As priority specialities are mentioned - cardiovascular diseases, oncology, children (perinatal, neo-natal) and mental health. As benefit receivers can qualify - Medical doctors, doctor's assistants, nurses, nurse's assistants, midwives, physiotherapists and ergotherapists [13].

Another section of the programme is dedicated specially for GPs - to promote senior GPs to transmit their practice to young GP. Receivers on this section are senior GP of the retirement age who hands over their practice and the new GP who takes over this practice.

In the interviews with representatives of the health care sector all of them positively evaluated the program and characterised it as one of the good ways to improve the situation in health care, especially if the funding is used from EU Funds.

Representatives of the Ministry of Health, who are the program implementers, evaluated this program as very successful. The development of the program was prolonged and the program was conformed only from December 1, 2017. The participants could apply for the 
Table 5. Applicants for program SAM 9.2.5. [Data from The Ministry of Health].

\begin{tabular}{|l|c|c|}
\hline Indicator & $\mathbf{1 0 . 0 9 . 2 0 1 8}$ & $\mathbf{1 5 . 1 1 . 2 0 1 8}$ \\
\hline Total applicants & 149 & 264 \\
\hline Reviewed & 78 & 181 \\
\hline Approved & 72 & 163 \\
\hline Rejected & 6 & 18 \\
\hline Applicants by speciality & & \\
\hline Doctor & 14 & 29 \\
\hline Doctor's Assistant & 40 & 58 \\
\hline Nurse & 28 & 45 \\
\hline Nurse's assistant & 60 & 124 \\
\hline Midwife & 2 & 3 \\
\hline Physiotherapist & 3 & 5 \\
\hline Ergotherapist & 0 & 0 \\
\hline GP applicants - total & 3 & 3 \\
\hline Reviewed & 0 & 2 \\
\hline Approved & 0 & 2 \\
\hline Rejected & 0 & 0 \\
\hline
\end{tabular}

programme since May, 2018 when the program was officially opened. During the first three months, till September 10, 2018, the Ministry of Health received 149 applications. At that time half of them -78 were already reviewed and 72 applicants qualified to receive the support. The project team pointed out that the rate of interest is higher than it was predicted and the number of applicants is higher than the capacity to review. The project team is very satisfied with reached outcomes. The number of applicants and the status of application are represented on Table 5.

The outcome indicators of this programme till the end of the project in 31.12 .2023 - is the number of medical specialists attracted to work in regions in priority specialities in amounts to 1420 (with intermediate goal on 31.12.2020 - 709). The number of GP practices that are undertaken by young GPs from retired GPs -100 .

As can be seen from the program results on Table 5, the total number of applications is high, and the overall goal can be reached even faster than planned, but if making deeper analysis of data, results are not satisfactory. According to human resource characterization, the main problem is human resource in Healthcare is the deficit of nurses and aging GPs.

Representatives of Medical Nurses association pointed out that the main problem with the deficit of nurses is not in rural clinics, but on the contrary - the deficit is in large state clinics in Riga and in some GPs practices. Therefore the interest rate in this category is not high and the program SAM 9.2.5. will not solve the problem. Of course, the fact that more nurses are attracted to work in health care is positive. However, the program support can be received only in case if the nurse is not already working in health care sector, and 45 nurses attracted to work in regions is not a significant accomplishment in the situation with nurse deficit of at least 800 in Latvia.

Representatives of association of Rural GPs of Latvia, commenting on results pointed to two reasons: the first - the amount of compensation that is paid to GP who gives away its practice is not adequate. The investments that GPs make to create and maintain the practice are more times higher than the compensation rate. In this situation, GPs are not motivated to give up their practice, and only in extreme situations, they agree on this program terms. 
Therefore, the interest is so low. The other factor is that this programme is meant only for rural regions, but not for Riga city. But the majority of the retired GPs are the ones who practice in Riga. Based on this, representatives of GPs are very sceptical on the outcomes of this program.

\section{Conclusions}

Evaluation of the existing solutions that are provided by the State and municipalities to solve the problem of shortage of human resources in healthcare leads to conclusion that the state paid residency programme with priority to a candidate who commits themselves to work in regions for at least 3 years after graduation - is very successful.

The programmes developed and implemented by municipalities to attract workforce in regions have different outcomes, some are successful, some are less and there are a plenty of different factors that impact on those results. Basing on the results and feedback from graduates, municipality paid residency in medicine was highly evaluated. The other programmes and stimuli are not so attractive and are suitable for some specialities only, depending on regional institution specialization, demand and other factors.

The state run program SAM 9.2.5. giving a specific support for specialists in priority specialities and the compensation mechanisms has some good results and can be evaluated as successfully implemented, but according to evaluation of representatives of medical specialist associations, would not significantly impact on the results and solve the human resource problems.

That leads to conclusion that available programmes provided by the state, as well as municipalities - can solve only part of the problem. Short time reimbursement cannot solve low salary problem and lack of possibilities to earn more in long-term perspective.

As all of the interviewed representatives mentioned, while salaries in healthcare sector stay at the present level, working in other sectors and countries is more attractive than working in healthcare, and shortage of human resources will still exist.

At the end of 2018, the Parliament made changes in Healthcare financing law to raise the funding for healthcare domain by 20 percent averagely, but still after this increase the average salary in healthcare sector is lower than the average in the state. Considering the fact that deficit of human resources in health care is acute in both rural regions and in Riga there should be more comprehensive and better funded programmes implemented and run by the state.

\section{References}

[1] Central Statistic Bureau of Latvia, Social Processes. Health. Self-perceived Health Status (EU-SILC). VPG072. Reasons for unmet need for medical care (except dental) for persons aged 16 or over (\%). Latest update 1/17/2019 [viewed 29.01.2019]

[2] OECD Data, Health Spending. Out of pocket as percentage of Health spending. Available at: https://data.oecd.org/healthres/health-spending.htm\# indicator-chart [viewed 03.02.2019]

[3] Konkurences padome, Medicinnas pakalpojumu tirgus uzraudzība. Noslēguma zingojums (Rīga, 2016)

[4] OECD Data. Health, Doctors total per 1000 inhabitants. Available at: https:// data.oecd.org/healthres/doctors.htm\#indicator-chart [viewed 03.02.2019] 
[5] OECD Data, Health. Nurses total per 1000 inhabitants. Available at: https://data.oecd.org/healthres/nurses.htm\#indicator-chart [viewed 03.02.2019]

[6] OECD Data, Health. Medical graduates total per 100000 inhabitants. Available at: https://data.oecd.org/healthres/medical-graduates.htm\#indicatorchart [viewed 03.02.2019]

[7] OECD Data, Health. Nursing graduates total per 100000 inhabitants. Available at: https://data.oecd.org/healthres/nursing-graduates.htm\#indicatorchart [viewed 03.02.2019]

[8] Ministru Kabinets, 07.08.2017 Rīkojums Nr.394. Konceptuālais ziņojums "Par veselības aprūpes sistēmas reformu"

[9] Pilsonības un Migrācijas lietu pārvalde, Iedzīvotāju registra statistika. Iedzīvotāju skaits pašvaldībās 01.07.2018. Available at: https://www.pmlp.gov.lv/lv/ assets/documents/statistika/Iedz $\%$ C4\%ABvot $\%$ C4\%81 ju \%20re $\%$ C4\%A3istrs $\% 20$ st. $\% 20 u z \% 2001072018 /$ ISPV_Pasvaldibas_iedzivotaju_skaits_ pagasti.pdf [viewed 04.02.2019]

[10] LTV Ziņudienests, Staicele palikusi bez ǵimenes ārsta. 26.01.2019 Available at: https://www.lsm.lv/raksts/zinas/latvija/staicele-palikusi-bezgimenes-arsta.a307404/ [viewed 04.02.2019]

[11] Slimību profilakses un kontroles centrs, Statistika, Veselības aprūpes cilvēkresursi Statistikas dati par veselības aprūpes cilvēkresursiem. Available at: https://www . spkc.gov. Iv/upload/Veselibas $\% 20$ aprupes $\% 20$ statistika/Statistikas $\%$ 20dati/2018/cilvekresursi_19122018.xlsx [viewed 04.02.2019]

[12] World Bank, Proscpects for Health Sector Reform in Latvia. November 2016. Available at: http://www.vmnvd.gov.lv/uploads/files/585933cb1d0d4.pdf [viewed 04.02.2019]

[13] Veselības ministrija, ESF Projekts "Ārstniecības un ārstniecības atbalsta personu pieejamības uzlabošanas ārpus Rīgas”. Available at: https://talakizglitiba. lv/projekti/kompensacijas-arstniecibas-personam-par-darbu-regionos [viewed 09.02.2019] 